\title{
Analisa Eksistensi Pengembangan Pendidikan dan Pelatihan Pegawai terhadap Produktivitas Kerja pada Dinas Perhubungan Komunikasi dan Informatika Tapanuli Tengah
}

\author{
Mansur Tanjung \\ mansurtanjung@yahoo.co.id \\ STIE Al-Washliyah Sibolga \\ Lambok Pardede \\ STIE Al-Washliyah Sibolga
}

\begin{abstract}
Abstrak
Produktivitas kerja dipengaruhi berbagai faktor antara lain pendidikan, pelatihan, disiplin, sikap, etika, motivasi, teknologi, penghasilan dan upah, perusahaan harus berusaha menjaga agar faktor yang berpengaruh terhadap produktivitas kerja terpenuhi secara maksimal. Pada dasarnya SDM sangat berkaitan dengan produktivitas kerja, maka produktivitas SDM masih perlu ditingkatkan melalui program pendidikan dan pelatihan. Program pendidikan dan pelatihan sebaiknya disusun dengan cermat berdasarkan metode ilmiah dan berpedoman pada keterampilan yang dibutuhkan. Teknik pengumpulan data yang digunakan adalah penelitian kepustakaan dan lapangan serta angket yang membuat daftar pertanyaan yang menyangkut objek penelitian yang di isi dan dijawab oleh responden.

Dilakukan beberapa pengujian untuk mengetahui pengaruh eksistensi pengembangan pendididkan dan Pelatihan (Diklat) pegawai terhadap produktivitas kerja. Dari perhitungan koefisien korelasi, untuk melihat hubungannya diperoleh sebesar 0,741. Hal ini termasuk dalam korelasi tinggi.

Dari perhitungan persamaan garis regresi linier variabel $\mathrm{X}$ dan variabel $\mathrm{Y}$ adalah : $\mathrm{Y}$ $=1,55+0,97 \mathrm{x}$. Dalam hal ini antara variabel $\mathrm{X}$ (pemberian diklat) dengan variabel $\mathrm{Y}$ (produktivitas) adalah kearah positif, artinya apabila nilai $\mathrm{X}($ pemberian diklat $)=$ nol maka variabel $\mathrm{Y}$ (produktivitas) $=1,55$ dan apabila variabel $\mathrm{X}$ (pemberian diklat) $=1$, maka variabel $\mathrm{Y}$ (produktivitas) $=2,52$

Untuk melihat seberapa besar pengaruhnya dilakukan perhitungan koefisien determinasi dan hasilyang diperoleh sebesar 54,91\% dan sisanya sebesar 45,09 \% dipengaruhi oleh variabel lain seperti, variabel kepemimpinan, kinerja, motivasi, dan lain-lain. Dilakukan uji hipotesis dengan membandingkan nilai t hitung dengan nilai $\mathrm{t}$ tabel, hasil yang diperoleh nilai $\mathrm{t}$ hitung $>$ dari nilai $\mathrm{t}$ tabel $(6,149>2,0)$ maka hipotesis dapat diterima.
\end{abstract}

Kata Kunci Akuntatabilitas, Pelayanan KTP, KK, dan Perizinan

\section{PENDAhuluan}

Manajemen Sumber Daya Manusia (MSDM) adalah bidang strategi dari organisasi. Penyusunan strategi sumber daya manusia harus memiliki relevansi dengan penyusunan strategi bisnis. Tujuan MSDM untuk meningkatkan kontribusi pegawai terhadap organisasi dalam rangka pencapaian produktivitas organisasi. Produktivitas kerja dipengaruhi oleh berbagai faktor antara lain pendidikan, pelatihan, disiplin, sikap, etika, motivasi, teknologi, penghasilan dan upah, tentunya perusahaan harus berusaha 
untuk menjaga agar faktor yang berpengaruh terhadap produktivitas kerja dapat terpenuhi secara maksimal. Pada dasarnya SDM sangat berkaitan dengan produktivitas kerja yaitu kemampuan pegawai dalam berproduksi atau dalam menghasilkan sesuatu dibandingkan dengan penggunaan SDM yang ada dalam sebuah organisasi tersebut, maka dari itu produktivitas SDM masih perlu ditingkatkan dengan salah satunya melalui program pendidikan dan pelatihan. Program pendidikan dan pelatihan hendaknya disusun secara cermat dan didasarkan pada metode-metode ilmiah serta berpedoman pada keterampilan yang dibutuhkan oleh organisasi saat ini maupun masa yang akan datang. Pendidikan pelatihan bertujuan meningkatkan kemampuan dan keterampilan agar produktivitas SDM meningkat sesuai dengan keterampilan yang sudah diperolehnya, sehingga kemungkinan SDM dapat mengembangkan diri dan memungkinkan untuk meraih kesempatan mendapatkan jabatan yang lebih tinggi.

Pengalaman juga merupakan modal sangat berarti dalam menjalankan roda organisasi, pengalaman yang telah dimiliki belum tentu selalu dapat digunakan sebagai alat yang ampuh untuk melaksanakan tugas yang selalu dipengaruhi oleh perkembangan yang terjadi. Hal tersebut berarti pula bahwa orang yang paling berpengalaman sekalipun tetap memerlukan tambahan pendidikan dan pelatihan. Pentingnya pendidikan dan pelatihan bukanlah semata-mata bermanfaat bagi pegawai yang bersangkutan tetapi juga keuntungan organisasinya.

Indikator pengembangan pendidikan dan pelatihan pegawai yang berhubungan terhadap peningkatan produktivitas kerja pegawai sebagai objek pembahasan ini, sedangkan alasan memilih pada Dinas Perhubungan Komunikasi dan informatika Kabupaten Tapanuli Tengah sebagai organisasi yang akan diteliti adalah karena tugas Dinas Perhubungan Komunikasi dan informatika Kabupaten Tapanuli Tengah yang cukup banyak memberikan penawaran jasa telekomunikasi baik yang langsung dan tidak bersentuhan dengan masyarakat dan instansi pemerintahan sehingga produktivitas kerja pegawai yang diharapkan dari para pegawai dapat meningkat agar organisasi dapat terus eksis dan maju dalam memberikan pelayanan kepada masyarakat.

Identifikasikan masalah yang ditemukan adalah apakah ada pengaruh eksistensi pengembangan pendididkan dan Pelatihan (Diklat) pegawai terhadap produktivitas kerja pada Dinas Perhubungan Komunikasi dan informatika Kabupaten Tapanuli Tengah ?, bagaimanakah pengaruh kesejahteraan pegawai terhadap produktivitas kerja pada Dinas Perhubungan Komunikasi dan informatika Kabupaten Tapanuli Tengah ?, bagaimana kualitas sumber daya manusia terhadap produktivitas kerja pada Dinas Perhubungan Komunikasi dan informatika Kabupaten Tapanuli Tengah ?, bagaimana kelengkapan sarana dan prasarana dalam meningkatkan produktivitas kerja pada Dinas Perhubungan Komunikasi dan informatika Kabupaten Tapanuli Tengah?, bagaimanakah peranan motivasi pimpinan terhadap peningkatan produktivitas kerja pada Dinas Perhubungan Komunikasi dan informatika Kabupaten Tapanuli Tengah?

\section{TINJAUAN PUSTAKA}

\section{A. Pengertian Eksistensi}

Menurut Zainal Abidin (2007:16) eksistensi adalah "Suatu proses yang dinamis, suatu menjadi atau mengada". Ini sesuai dengan asal kata eksistensi itu sendiri, yakni exsistere, yang artinya keluar dari, melampaui atau mengatasi” (Abidin, 2007). Jadi eksistensi tidak bersifat kaku dan terhenti, melainkan lentur atau kenyal dan mengalami perkembangan atau sebaliknya kemunduran, tergantung pada kemampuan dalam mengaktualisasikan potensi - potensinya.

Adapun yang dimaksud eksistensi di dalam penelitian ini adalah eksistensi pendidikan dan pelatihan (Diklat) dalam upaya meningkatkan kinerja pegawai. Jika melihat pengertian eksistensi di atas maka eksistensi pengembangan keterampilan pegawai dapat dikatakan tetap eksis apabila produktivitas kerja pegawai meningkat. 


\section{B. Teoritis pengembangan pendidikan dan pelatihan (Diklat) pegawai}

\section{Pengertian pengembangan pegawai}

Setiap perusahaan dituntut untuk siap dan peka dalam menghadapi perubahan lingkungan organisasi perusahaan yang semakin cepat dan kompleks. Perusahaan yang dinamis akan berusaha mengantisipasi dan menyesuaikan diri terhadap segala pengaruh lingkungan organisasi, baik lingkungan makro maupun lingkungan mikro. Salah satu usaha untuk mengantisipasi perubahan lingkungan organisasi tersebut adalah dengan mengembangkan kualitas dan keterampilan sumber daya manusia dalam organisasi. Mathis menyatakan bahwa pengembangan adalah "Usaha-usaha untuk meningkatkan kemampuan pegawai dalam lingkungan pekerjaan untuk menghadapi berbagai penugasan" (Prawira, 2002). Ranupandojo dan Hasan menyatakan "Pengembangan pegawai sering diartikan dengan usaha-usaha untuk meningkatkan keterampilan maupun pengetahuan umum bagi pegawai agar pelaksanaan pencapaian tujuan lebih efisien" (Ranupandojo, et al., 2004).

Pengembangan pegawai lewat pendidikan dan latihan untuk memperbaiki kerja seorang pegawai dengan cara meningkatkan pengetahuan, keterampilan dan sikap guna mencapai peningkatan kualitas kerja yang diharapkan.

\section{Tujuan dan manfaat pengembangan pegawai}

Pengembangan pegawai bertujuan dan bermanfaat bagi perusahaan, pegawai, konsumen atau masyarakat yang mengkonsumsi barang/jasa yang dihasilkan perusahaan. Tujuan pengembangan menurut Malayu SP. Hasibuan, (2007:70) hakikatnya menyangkut hal-hal berikut:

a. Produktivitas. Produktivitas kerja pegawai akan meningkatkan kualitas dan kuantitas produksi semakin baik, karena technical skill, human skill dan manajerial skill pegawai yang semakin baik

b. Efisiensi. Meningkatkan efisiensi tenaga, waktu, bahan baku dan mengurangi ausnya mesin-mesin, pemborosan berkurang, biaya produksi relatif kecil sehingga daya saing perusahaan semakin besar.

c. Kerusakan. Mengurangi kerusakan barang, produksi dan mesin-mesin arena pegawai semakin ahli dan terampil dalam melaksanakan pekerjaannya.

d. Kecelakaan. Tingkat kecelakaan pegawai dapat dikurangi sehingga jumlah biaya pengobatan yang dikeluarkan perusahaan berkurang.

e. Pelayanan. Peningkatan pelayanan yang lebih baik dari pegawai kepada nasabah perusahaan karena pemberian pelayanan yang baik merupakan daya penarik yang sangat penting bagi rekanan-rekanan perusahaan yang bersangkutan.

f. Moral. Moral pegawai akan lebih baik karena keahlian dan keterampilannya sesuai dengan pekerjaannya sehingga antusias untuk menyelesaikan pekerjaannya dengan baik.

g. Karier. Kesempatan untuk meningkatkan karier pegawai semakin besar, karena keahlian, keterampilan dan prestasi kerjanya lebih baik. Promosi ilmiah biasanya didasarkan kepada keahlian dan prestasi kerja seseorang.

h. Konseptual. Manajer semakin cakap dan cepat dalam mengambil keputusan yang lebih baik karena technical skill, human skill dan manajerial skillnya lebih baik.

i. Kepemimpinan. Kepemimpinan seorang manajer akan lebih baik, human relationsnya lebih luwes, motivasinya lebih terarah sehingga pembinaan kerjasama semakin harmonis.

j. Balas jasa. Balas jasa (Gaji, upah, insentif dan benefit) pegawai akan meningkat karena prestasi kerja mereka semakin besar. 
k. Konsumen Memberikan manfaat yang baik bagi masyarakat konsumen karena mereka akan memperoleh barang atau pelayanan yang lebih bermutu.

Selanjutnya, Malayu SP. Hasibuan, (2007:72) menjelaskan beberapa manfaat yang

perusahaan peroleh dalam melaksanakan penyelenggaraan suatu pelatihan :

a. Peningkatan produktivitas kerja organisasi sebagai keseluruhan antara lain karena tidak terjadinya pemborosan, karena kecermatan melaksanakan tugas, tumbuh suburnya kerjasama antara berbagai satuan kerja yang melaksanakan berbagai kegiatan yang berbeda dan bahkan spesialistik, meningkatnya tekad mencapai sasaran yang telah ditetapkan.

b. Terwujudnya hubungan yang serasi antara atasan dan bawahan antara lain karena adanya pendelegasian wewenang, interaksi yang didasarkan pada sikap dewasa yang baik secara teknikal maupun intelektual, saling menghargai dan adanya kesempatan bagi bawahan untuk berfikir dan bertindak secara inovatif.

c. Terjadinya proses pengambilan keputusan yang lebih cepat dan tepat karena melibatkan para pegawai yang bertanggung jawab menyelenggarakan kegiatankegiatan operasional dan tidak sekedar diperintahkan oleh manajer.

d. Meningkatkan semangat kerja seluruh tenaga kerja dalam organisasi dengan komitmen organisasi yang lebih tinggi.

e. Mendorong sikap keterbukaan manajemen melalui penerapan gaya manajemen yang partisipatif

f. Memperlancar jalannya komunikasi yang efektif yang pada gilirannya memperlancar proses perumusan kebijaksanaan organisasi dan operasionalisasinya.

g. Penyelesaian konflik secara fungsional yang dampaknya adalah tumbuh suburnya rasa persatuan dan suasana kekeluargaan di kalangan para anggota organisasi

\section{Pengembangan pegawai melalui pendidikan dan pelatihan}

Pelaksanaan pengembangan (Latihan dan pendidikan) harus didasarkan pada metodemetode yang telah ditetapkan dalam program pengembangan perusahaan. Program pengembangan ditetapkan oleh penanggung jawab pengembangan, yaitu manajer personalia dan atau suatu tim.

Dalam program pengembangan telah ditetapkan sasaran, proses, waktu, dan metode pelaksanaanya. Supaya lebih baik program ini hendaknya disusun oleh manajer personalia dan atau suatu tim serta mendapat saran, ide maupun kritik yang bersifat konstruktif. Menurut Mondy R.W (2008:78) Metode-metode pengembangan harus didasarkan kepada sasaran yang ingin dicapai antara lain :

a. Meningkatkan kemampuan dan keterampilan teknis mengerjakan pekerjaan atau technical skills dari setiap karyawan setelah mengikuti kegiatan pengembangan

b. Meningkatkan keahlian dan kecakapan memimpin serta mengambil keputusan atau managerial skills dan conceptual skills.

Lebih lanjut menurut Mondy R.W (2008:80) metode Pengembangan terdiri atas :

a. Metode Latihan atau Training Metode-metode Latihan yang dapat dilaksanakan antara lain:

1) On the Job. Para peserta latihan langsung bekerja di tempat untuk belajar dan meniru suatu pekerjaan di bawah bimbingan seorang pengawas. 
2) Vestibule. Metode latihan yang dilakukan dalam kelas atau bengkel yang biasanya diselenggarakan dalam suatu perusahaan industri untuk memperkenalkan pekerjaan kepada karyawan baru dan melatih mereka mengerjakan pekerjaan tersebut.

3) Demonstration and Example. Demonstration and Example adalah metode latihan yang dilakukan dengan cara peragaan dan penjelasan bagaimana cara-cara mengerjakan sesuatu pekerjaan melalui contoh-contoh atau percobaan yang didemonstrasikan

4) Simulation. Simulasi merupakan suatu teknik untuk mencontoh semirip mungkin terhadap konsep sebenarnya dari pekerjaan yang akan dijumpainya.

5) Apprenticeship. Suatu cara untuk mengembangkan keahlian pertukangan sehingga para karyawan yang bersangkutan dapat mempelajari segala aspek dari pekerjaannya.

b. Classroom Methods

1) Lecture (Ceramah atau kuliah). Metode kuliah diberikan kepada peserta yang banyak di dalam kelas. Pelatih mengajarkan teori-teori yang diperlukan sedang yang dilatih mencatatnya serta mempersepsikannya.

2) Conference (rapat). Pelatih memberikan suatu makalah tertentu dan peserta pengembangan ikut serta berpartisipasi dalam memecahkan makalah tersebut. Mereka harus mengemukakan ide dan sarannya untuk didiskusikan serta diterapkan kesimpulannya.

3) Programmed instruction. Program instruksi merupakan bentuk training sehingga peserta dapat belajar sendiri karena langkahlangkah pengerjaan sudah diprogram, biasanya dengan komputer, buku, atau mesin pengajar.

4) Metode studi kasus. Dalam teknik studi kasus, pelatih memberikan suatu kasus kepada peserta pengembangan yang tidak disertai dengan data yang lengkap atau sengaja disembunyikan, tujuannya agar peserta terbiasa mencari data/informasi dari pihak eksternal dalam memutuskan suatu kasus yang dihadapinya. Peserta ditugaskan untuk mengidentifikasi masalah, menganalisis situasi, dan merumuskan penyelesaiannya.

5) Role Playing. Teknik dalam metode ini, beberapaorang peserta ditunjuk untuk memainkan suatu peran dalam sebuah organisasi tiruan, jadi semacam sandiwara.

6) Metode diskusi. Metode diskusi dilakukan dengan melatih peserta untuk berani memberikan pendapat dan rumusannya serta cara-cara bagaimana meyakinkan orang lain percaya terhadap pendapatnya.

7) Metode seminar. Metode seminar bertujuan mengembangkan keahlian dan kecakapan peserta unuk menilai dan memberikan saransaran yang konstruktif mengenai pendapat orang lain (pembawamakalah). Peserta dilatih agar dapat mempersepsi, mengevaluasi, dan memberikan saran-saran serta menerima atau menolak pendapat atau usul orang lain

4. Pengertian Pendidikan dan Pelatihan

Sekolah Tinggi Ilmu Ekonomi (STIE) Al-Washliyah Sibolga 
Istilah pendidikan dan pelatihan sering menimbulkan keraguan dan disalahartikan dengan istilah-istilah yang dewasa ini lebih banyak digunakan dalam politik, yakni pengembangan. Keraguan dan ketidakpastian itu sebenarnya tidak perlu terjadi, karena pada hakikatnya pengertian yang dalam istilah-istilah tersebut memang memiliki kaitan yang erat satu sama lainnya dan menunjukkan suatu kegiatan yang sama, yakni usaha/kegiatan peningkatan pengetahuan, keterampilan dan sikap pegawai operasional maupun pegawai manajemen.

Siswanto Sastrohadiwiryo (2003:45) menyatakan bahwa pendidikan dan pelatihan (development) mempunyai ruang lingkup yang lebih luas untuk memperbaiki dan meningkatkan pengetahuan, kemampuan, sikap dan sifat-sifat kepribadian. Sedangkan Malayu SP. Hasibuan (2005:27) memberikan pengertian pendidikan dan pelatihan adalah suatu usaha untuk meningkatkan kemampuan teknis, teoritis, konseptual dan moral pegawai sesuai dengan kebutuhan pekerjaan/jabatan melalui pendidikan dan pelatihan.

Dari kedua definisi di atas dapat disimpulkan bahwa pendidikan dan pelatihan pegawai merupakan masalah penting dalam perusahaan karena untuk mencapai tujuan-tujuan dari perusahaan diperlukan tenaga-tenaga yang berkualitas dan terampil dan ini hanya diperoleh melalui pendidikan dan pelatihan. Jadi jelaslah bahwa pendidikan dan pelatihan pegawai dalam suatu perusahaan merupakan upaya untuk meningkatkan keterampilan maupun pengetahuan pegawai, di mana pada akhirnya akan meningkatkan kecakapan pegawai dalam pencapaian tujuan yang telah ditetapkan

\section{Tujuan Pendidikan dan Pelatihan}

Untuk menghadapi tuntutan dan tugas sekarang dan terutama untuk menjawab tantangan masa depan, pendidikan dan pelatihan pegawai merupakan keharusan mutlak. Kemutlakan itu tergambar pada berbagai jenis manfaat yang dapat dipetik dari padanya, baik organisasi, para pegawai maupun bagi pertumbuhan dan pemeliharaan hubungan yang serasi antara berbagai kelompok kerja dalam suatu organisasi. Berarti semuanya bermuara pada peningkatan produktivitas kerja organisasi secara keseluruhan.

Menurut Malayu SP. Hasibuan (2005:29) ada beberapa tujuan yang ingin dicapai

dengan mengadakan pendidikan dan pelatihan antara lain sebagai berikut:

a. Produktivitas kerja. Dengan pendidikan dan pelatihan maka produktivitas kerja pegawai akan meningkatkan, kualitas dan kuantitas produksi semakin baik, karena technical skill, managerial skill pegawai yang semakin baik.

b. Efisiensi. Pendidikan dan pelatihan bertujuan untuk meningkatkan efisiensi tenaga kerja, waktu, bahan baku, dan mengurangi pemakaian mesin-mesin ecara berlebihan. Pemborosan berkurang, biaya produksi relatif kecil sehingga daya saing perusahaan semakin besar.

c. Kerusakan. Pendidikan dan pelatihan bertujuan untuk mengurangi kerusakan barang, produksi dan mesin-mesin karena pegawai semakin ahli dan terampil dalam melaksanakan pekerjaannya.

d. Kecelakaan. Pendidikan dan pelatihan bertujuan untuk mengurangi tingkat kecelakaan pegawai, sehingga jumlah biaya pengobatan yang keluarkan perusahaan berkurang.

e. Pelayanan. Pendidikan dan pelatihan bertujuan untuk meningkatkan pelayanan yang lebih baik dari pegawai kepada nasabah perusahaan, karena pemberian pelayanan yang baik merupakan daya menarik yang sangat penting bagi rekanan-rekanan perusahaan bersangkutan. 
f. Moral. Dengan pendidikan dan pelatihan, maka moral pegawai akan lebih baik karena keahlian dan keterampilan sesuai dengan pekerjaannya sehingga mereka antusias untuk menyelesaikan pekerjaannya dengan baik

g. Karier. Dengan pendidikan dan pelatihan, kesempatan untuk meningkatkan karier pegawai semakin besar, karena keahlian, keterampilan dan kinerjanya lebih baik. Promosi ilmiah biasanya didasarkan kepada keahlian dan kinerja seseorang.

h. Konseptual. Dengan pendidikan dan pelatihan, manajer semakin cakap dan cepat dalam pengambilan keputusan yang lebih baik, karena technical skill, human skill dan managerial skill-nya telah lebih baik.

i. Balas jasa. Dengan pendidikan dan pelatihan, maka balas jasa (gaji, upah insentif dan benefits) pegawai akan meningkat karena kinerja mereka semakin besar.

\section{Prinsip -Prinsip Manajemen Pendidikan dan Pelatihan}

Pengelolaan manajemen pelatihan tidak berlangsung begitu saja melainkan melalui serangkaian proses kegiatan berupa pengetahuan, pemahaman, sikap dan keterampilan, hal ini dikemukakan oleh beberapa ahli di bawah ini. Pengetahuan, pemahaman, sikap, dan keterampilan atas sesuatu oleh seseorang senantiasa diperoleh melalui proses belajar. Proses belajar dapat dilakukan dengan sengaja dapat juga tanpa rencana. Proses belajar itu dapat secara terprogram maupun tanpa program. Belajar diperlihatkan melalui perubahan tingkah laku sebagai hasil pengalaman, yang diperoleh pembelajar melalui interaksi dengan lingkungannya dalam rangka memenuhi kebutuhan hidupnya. Menurut S. Martoyo (2000:36) perubahan tingkah laku dalam belajar memiliki enam karakteristik, yakni :
a. Terjadi secara sadar
b. Bersifat kontinu dan fungsional
c. Bersifat positif dan aktif
d. Besifat permanen, bukan sementara
e. Bertujuan atau terarah
f. Mencakup seluruh aspek tingkahlaku.

Selanjutnya, S. Martoyo (2000:37) menyetakan bahwa "Belajar merupakan proses psikologis yang mengubah tingkah laku individu, yang berupa kemampuan aktual dan potensial, yang berlaku dalam waktu yang relatif lama dan diperoleh dengan usaha sadar" Proses pembelajaran yang dilakukan oleh pengajar dan pembelajar seringkali digunakan istilah pendidikan, pembinaan, dan pelatihan.

Pendidikan mengacu kepada komunikasi yang terorganisasi dan diarahkan untuk menumbuhkan kegiatan belajar; pembinaan mengacu kepada usaha, tindakan, dan kegiatan yang dilakukan secara berdaya guna dan berhasil guna untuk memperoleh hasil yang lebih baik; sedangkan pelatihan mengacu kepada usaha, proses, atau kegiatan yang dilakukan untuk mencapai keterampilan. Keberhasilan pembelajaran dipengaruhi oleh trikondisi pendidikan, yakni konsistensi, konvergensi, dan kontinuitas. Konsistensi berarti bahwa kegiatan pendidikan harus serasi dalam mengembangkan potensi peserta

\section{Teoritis produktivitas}

\section{Pengertian produktivitas}

Menurut Marvin E. Mundel (2011:47) produktivitas adalah "Rasio keluaran yang menghasilkan untuk penggunaan di luar organisasi yang memperbolehkan untuk berbagai macam produk dibagi oleh sumber-sumber yang digunakan, semuanya dibagi dengan rasio yang sama dari periode dasar“. Setiap organisasi/instansi selalu berupaya untuk meningkatkan 
kualitas sumber daya manusia, karena dengan meningkatkan kualitas sumber daya manusia maka sudah barang tentu akan meningkatkan produktivitas kerja pegawai .

Menurut Muchdarsyah Sinungan (2009:82) produktivitas sebagai "Perbandingan antara totalitas pengeluaran pada waktu tertentu dibagi totalitas masukan selama periode tersebut". Produktivitas mengutamakan cara memanfaatkan secara baik terhadap sumbersumber dalam memproduksi barang-barang. Selanjutnya, Sedarmayanti (2001:71) menyebutkan produktivitas kerja menunjukan bahwa individu merupakan perbandingan dari efektivitas keluaran (pencapaian untuk kerja maksimal)“.

Kemudian, menurut Malayu S.P. Hasibuan (2009:127) bahwa produktivitas adalah "Perbandingan secara ilmu hitung antara jumlah yang dihasilkan dengan jumlah setiap sumber yang dipergunakan selama produksi berlangsung". Menurut pengertian tersebut produktivitas dapat dihitung dengan membandingkan jumlah produk yang dihasilkan dengan sumbersumber yang digunakan untuk menghasilkan produk. Produktivitas menurut Kisdarto Atmosoeparto (2000:1) adalah "Suatu ukuran sejauh mana sumber daya dipergunakan dan digabungkan dalam mewujudkan hasil yang di inginkan“.

Dari beberapa pengertian tersebut di atas dapat di simpulkan bahwa produktivitas tersebut merupakan perbandingan hasil yang diperoleh oleh perusahaan dari jumlah masukan yang dilakukan oleh pegawai , sehingga dapat diambil suatu kesimpulan apakah perusahaan tersebut mampu meningkatkan produktivitas kerjanya dari hasil yang telah dilakukan oleh pegawai itu sendiri dalam jangka waktu tertentu.

\section{Manfaat produktivitas Kerja}

Menurut Menurut Muchdarsyah Sinungan (2005:56) manfaat dari produktivitas adalah sebagai berikut :

a. Untuk memperkuat daya saing perusahaan, karena perusahaan dapat memproduksi dengan biaya yang lebih rendah dan mutu produksi yang lebih baik

b. Menunjang kelestarian dan perkembangan perusahaan karena dengan meningkatnya produktivitas perusahaan, akan memungkinkan memperoleh keuntungan yang dapat digunakan untuk investasi baru.

c. Meningkatkan standar hidup dan martabat pegawai

Dari uraian tersebut dapat disimpulkan bahwa manfaat dengan adanya produktivitas tersebut berguna untuk meningkatkan daya saing perusahaan serta menunjang kelestarian dan perkembangan perusahaan

\section{Pentingnya produktivitas}

Penilaian produktivitas kerja merupakan suatu proses dalam menilai produktivitas kerja pegawainya. Tujuan dilakukan penilaian kerja secara umum adalah untuk memberikan suatu masukan maupun informasi dalam upaya untuk memperbaiki tampilan kerja pegawai dalam meningkatkan produktivitas kerja pegawai itu sendiri, sehingga tujuan organisasi dapat tercapai. Sedangkan secara khusus tujuan penilaian produktivitas tersebut dilakukan pimpinan adalah sebagai bentuk tujuan promosi kerja atau kenaikan pendapatan penghasilan atau pelatihan dan pendidikan, dan lain lain.

Menurut Marihot Tua Effendi Hariandja (2002:195) bahwa arti pentingnya penilaian produktivitas kerja secara rinci dikemukakan sebagai berikut:

a. Perbaikan produktivitas kerja, memberikan kesempatan kepada pegawai untuk mengambil tindakan perbaikan untuk meningkatkan produktivitas.

b. Penyesuaian gaji, dapat dipakai sebagai informasi untuk menggaji pegawai secara layak sehingga dapat memotivasi 
c. Keputusan untuk penempatan, yaitu dapat dilakukan penempatan pegawai sesuai dengan keahliannya.

d. Pelatihan dan pengembangan yaitu melalui penilaian akan diketahui kelemahan dari pegawai sehingga dapat dilakukan pelatihan dan pengembangan yang efektif.

e. Perencanaan karir, yaitu organisasi dapat memberikan bantuan perencanaan bagi pegawai dan menyelaraskannya dengan kepentingan organisasi.

f. Mengidentifikasi kelemahan-kelemahan dalam proses penempatan, yaitu produktivitas kerja yang tidak baik menunjukkan adanya kelemahan dalam penempatan sehingga dapat dilakukan perbaikan.

g. Dapat mengidentifikasi adanya kekurangan dalam desain pekerjaan, yaitu kekurangan produktivitas kerja akan menunjukkan adanya kekurangan dalam perancangan.

\section{Indikator variabel penelitian}

\section{Indikator Pengembangan Pendidikan Dan Pelatihan (Diklat)}

Menurut Malayu SP. Hasibuan (2005:49) indikator yang mempengaruhi pendidikan dan pelatihan antara lain:
a. Peserta
b. Pelatih/Instruktur
c. Fasilitas Pendidikan dan Pelatihan
d. Kurikulum
e. Dana Pendidikan dan Pelatihan
Berdasarkan pendapat ahli diatas, lebih lanjut penulis menjelaskan :

Ad. a. Peserta

Peserta pendidikan dan pelatihan mempunyai latar belakang yang tidak sama atau heterogen seperti pendidikan dasarnya, pengalaman kerjanya, usianya dan lain sebagainya. Hal ini akan menyulitkan dan menghambat pelaksanaan pendidikan dan pelatihan karena daya tangkap, persepsi dan daya nalar mereka terhadap pelajaran yang diberikan berbeda.

Ad. b. Pelatih/Instruktur

Pelatih atau instruktur yang ahli dan pintar mentransfer pengetahuannya kepada para peserta latihan dan pendidikan sulit didapat. Akibatnya sasaran yang diinginkan tidak tercapai. Misalnya, ada pelatih yang ahli dan pintar tetapi tidak dapat mengajar dan berkomunikasi secara efektif atau teaching skillnya tidak efektif, jadi dia hanya pintar serta ahli untuk dirinya sendiri.

Ad. c. Fasilitas Pendidikan dan Pelatihan

Fasilitas sarana dan prasarana dibutuhkan untuk pendidikan dan pelatihan itu harus lengkap dak baik. Misalnya, buku-buku, alat-alat, mesin-mesin yang akan dipergunakan untuk praktek kurang atau tidak ada. Hal ini akan menghambat lancarnya pendidikan dan pelatihan

\section{Ad. d. Kurikulum}

Kurikulum yang ditetapkan dan diajarkan harus sesuai serta sistematis untuk mendukung sasaran yang diinginkan oleh pekerjaan atau jabatan.

Ad. e. Dana Pendidikan dan Pelatihan

Dana yang tersedia untuk pendidikan dan pelatihan harus sesuai dengan kebutuhan pendidikan dan pelatihan, sehingga pelatih maupun sarananya memenuhi persyaratan yang dibutuhkan 


\section{Indikator produktivitas pegawai}

Menurut Bernardin dalam Ambar T (2003:226) mengungkapkan ada 6 kriteria utama produktivitas yang dapat di nilai sebagai berikut :

a. Kualitas. Tingkat dimana proses atau hasil dari suatu kegiatan yang sempurna, melaksanakan kegiatan dengan cara ideal.

b. Kuantitas. Besaran yang dihasilkan dalam bentuk nilai, jumlah atau sejumlah kegiatan yang diselesaikan.

c. Ketepatan waktu. Tingkat dimana kegiatan diselesaikan, atau hasil yang diselesaikan dengan waktu yang lebih cepat dari waktu yang ditetapkan.

d. Efektifitas biaya. Tingkat dimana penggunaan sumber - sumber organisasi dimaksimalkan untuk mendapatkan target yang tertinggi atau sebaliknya.

e. Kebutuhan pengawasan. Tingkat dimana pegawai melaksanakan pekerjaannya tanpa harus dilakukan pengawasan atau sebaliknya untuk menghindari kesalahan

f. Pengaruh Interpersonal. Tingkat dimana pegawai menunjukkan perasaan harga diri, goodwill dan kerja sama diantara rekan sekerja dan bawahan.

\section{A. Akuntabilitas}

Dalam Keputusan Menteri PAN Nomor. 63/KEP/M.PAN/8/2013 dikatakan bahwa "Penyelenggaraan pelayanan publik harus dapat dipertanggungjawabkan, baik kepada publik maupun kepada atasan/pimpinan unit pelayanan instansi pemerintah sesuai dengan ketentuan peraturan perundang-undangan."

Menurut Miriam Budiarjo, (2010 : 74) mengartikan akuntabilitas sebagai Pertanggung jawaban pihak yang diberi mandat untuk memerintah kepada mereka yang memberi mandat itu. Akuntabilitas bermakna pertanggung jawaban dengan menciptakan pengawasan melalui distribusi kekuasaan ada berbagai lembaga pemerintah sehingga mengurangi penumpukan kekuasaan sekaligus menciptakan kondisi saling mengawasi.

Selanjutnya Bambang Istianto, (2009: 109) akuntabilitas diartikan "Setiap tugas dan tangggung jawab pemerintahan daerah harus diselenggarakan dengan baik karena setiap kebijakan dan tindakan yang diambil harus dapat dipertanggungjawabkan kehadapan publik maupun dari kacamata hukum."

"Akuntabilitas kinerja instansi pemerintahan adalah perwujudan kewajiban instansi pemerintah untuk mempertanggungjawabkan keberhasilan dan kegagalan pelaksanaan misi organisasi dalam mencapai sasaran dan tujuan yang telah ditetapkan melalui alat pertanggungjawaban secara periodik." (Gambir Bhatta, 2006 : 87).

\section{B. Pelayanan}

Pelayanan diartikan "Sebagai pemberian layanan (melayani) keperluan masyarakat yang mempunyai kepentingan pada organisasi itu sesuai dengan aturan pokok dan tata cara yang telah ditetapkan."(Sinambela, $2006: 5)$

Sedangkan Boediono (2003: 60) menyatakan bahwa, pelayanan juga disebut "Suatu proses bantuan kepada orang lain dengan cara-cara tertentu yang memerlukan kepekaan dan hubungan interpersonal agar terciptanya kepuasan dan keberhasilan."

Sesuai dengan Keputusan Menteri PAN Nomor. 63/KEP/M.PAN/8/2013, pelayanan publik dibagi berdasarkan 3 (tiga) kelompok, yaitu :

1. Kelompok pelayanan administratif, yaitu bentuk pelayanan yang menghasilkan berbagai macam dokumen resmi yang dibutuhkan oleh masyarakat atau publik.

2. Kelompok pelayanan barang, yaitu pelayanan yang menghasilkan berbagai bentuk/jenis barang yang digunakan publik. 
3. Kelompok pelayanan jasa, yaitu pelayanan yang menghasilkan berbagai bentuk jasa yang dibutuhkan publik

\section{METODE PENELITIAN}

Berdasarkan latar belakang masalah pokok dan hipotesis yang dikemukakan sebelumnya, maka metode analisis yang digunakan untuk pengujian dan pembuktian hipotesis adalah :

1. Analisis kualitatif.

Analisis kualitatif merupakan analisis data yang tidak dapat dinominasikan dengan menggunakan angka, melainkan disajikan berupa keterangan, penjelasan dan pembahasan teori.

2. Analisis kuantitatif.

Analisis kuantitatif adalah analisis data dalam bentuk angka-angka yang pembahasannya, melalui penghitungan statistik berdasarkan jawaban kuesioner dari responden. Hasil penghitungan dari skor atau nilai tersebut kemudian di analisis statistik untuk membuktikan hubungan antara variabelvariabel penelitian, dengan melakukan uji data sebagai berikut :

a. Koefisien korelasi.

Adapun rumus koefisien korelasi Karl Pearson Product Moment (Sugiyono 2012 : 250) untuk mengetahui hubungan kedua variabel tersebut sebagai berikut :

$$
\mathrm{r}_{\mathrm{xy}}=\frac{\mathrm{n} \cdot \Sigma \mathrm{XY}-\left(\sum \mathrm{X}\right) \cdot\left(\sum \mathrm{Y}\right)}{\sqrt{\left(\mathrm{n} \cdot \Sigma \mathrm{X}^{2}-\left(\sum \mathrm{X}\right)^{2}\right) \cdot\left(\mathrm{n} \cdot \Sigma \mathrm{Y}^{2}-\left(\sum \mathrm{Y}\right)^{2}\right)}}
$$

\section{Keterangan :}

$\mathrm{r}_{\mathrm{xy}}$ : Koefisien korelasi antara X dan Y

$\mathrm{X}$ : Variabel bebas (pimpinan)

Y : Variabel terikat (kualitas pelayanan publik)

$\mathrm{n}$ : Jumlah sampel

Untuk melihat hubungan kedua variabel tersebut, maka dapat dirumuskan sebagai berikut, :

1) Nilai $\mathrm{r}$ yang positif menunjukkan hubungan kedua variabel positif, artinya kenaikan nilai variabel yang satu diikuti oleh nilai variabel $\mathrm{Y}$.

2) Nilai $r$ yang negatif menunjukkan hubungan kedua variabel negatif, artinya menurunnya nilai variabel yang satu dengan diikuti meningkatnya nilai variabel yang lain.

3) Nilai $r$ yang sama dengan nol menunjukkan kedua variabel tidak menunjukkan hubungan, artinya variabel yang satu tetap meskipun yang lainya berubah.

Untuk mengetahui adanya hubungan yang tinggi, sedang atau rendah antara kedua variabel berdasarkan nilai r (koefisien korelasi) digunakan penafsiran atau interpretasi angka sebagai berikut

Tabel 1.Interprestasi Koefisien korelasi Sumber : Sugiyono (2012:250)

\begin{tabular}{|c|l|}
\hline Interprestasi Koefisien & Tingkat Hubungan \\
\hline $0.80-1.000$ & Sangat kuat \\
$0.60-0.799$ & kuat \\
$0.40-0.599$ & Sedang \\
$0.20-0.399$ & Rendah \\
$0.00-0.199$ & Sangat rendah \\
\hline
\end{tabular}


Setelah nilai $\mathrm{r}$ diperoleh, maka dapat diketahui apakah nilai $\mathrm{r}$ yang diperoleh berarti atau tidak dan bagaimana tingkat hubungannya melalui tabel korelasi. Tabel korelasi menentukan batas-batas $r$ yang signifikan.

b. Koefisien Determinasi.

Teknik ini digunakan untuk mengetahui berapa persen besarnya pengaruh variabel bebas/independen $(\mathrm{X})$ terhadap variabel terikat/ dependen $(\mathrm{Y})$, dilakukan perhitungan koefisien determinant dengan rumus sebagai berikut : $\mathrm{KD}=\mathrm{r}^{2} \mathrm{x} 100 \%$.

c. Analisis Regresi Linear Sederhana.

Adapun rumus yang digunakan untuk mencari regresi linear sederhana untuk melihat hubungan tersebut signifikan atau tidak dengan menggunakan rumus sebagai berikut :

$$
\mathrm{Y}=\mathrm{a}+\mathrm{bX}
$$

Untuk memperoleh garis regresi dibutuhkan data dari kedua variabel $\mathrm{X}$ dan variabel $\mathrm{Y}$, maka nilai (a) dan (b) dapat ditentukan dengan cara sebagai berikut :

$$
\begin{aligned}
\mathrm{a} & =\frac{\left(\sum y\right)\left(\sum x^{2}\right)-\left(\sum \mathrm{x}\right) \cdot\left(\sum x \mathrm{y}\right)}{\mathrm{n} \cdot\left(\sum x^{2}\right)-\left(\sum x\right)^{2}} \\
\mathrm{~b} & =\frac{n \cdot\left(\sum x y\right)-\left(\sum \mathrm{x}\right) \cdot\left(\sum \mathrm{y}\right)}{\mathrm{n} \cdot\left(\sum x^{2}\right)-\left(\sum x\right)^{2}}
\end{aligned}
$$

d. Uji Hipotesis $(\mathrm{Uji}-t)$

Untuk menguji hipotesis yang diajukan, maka diadakan pengujian dengan menggunakan rumus " $t$ " menurut Sugiyono (2012:272)yaitu :

$$
t=\frac{r \sqrt{n-2}}{\sqrt{1-r^{2}}}
$$

Degree of freedom $(\mathrm{df})=2$

Keterangan :

$\mathrm{r} \quad=$ korelasi $\mathrm{xy}$ yang ditemukan

$\mathrm{n}=$ jumlah sampel

$t=t_{\text {hitung }}$ yangselanjutnya dibandingkan dengan $\mathrm{t}_{\text {tabel }}$

Dengan taraf signifikan 0,05, uji dua arah dengan derajat kebebasan $(\mathrm{dk})=\mathrm{n}-2$.

Kriteria pengujian hipotesis sebagai berikut :

1) Apabila $t_{\text {hitung }} \geq t_{\text {tabel }}$, maka hipotesis alternatif $\left(H_{a}\right)$ diterima dan hipotesis nol $\left(\mathrm{H}_{\mathrm{O}}\right)$ ditolak.

2) Apabila $t_{\text {hitung }} \leq t_{\text {tabel }}$, maka hipotesis alternatif $\left(\mathrm{H}_{\mathrm{a}}\right)$ ditolak dan hipotesis nol $\left(\mathrm{H}_{\mathrm{O}}\right)$ diterima.

\section{PEMBAHASAN}

Hasil uji koefisien korelasi antara variabel penelitian diperoleh 0,63 hal ini memberi pengertian bahwa hubungan antara akuntabilitas kerja terhadap pelayananadalah kuat, hal ini sesuai dengan pendapat Sugiyono (2012 : 250) bahwa : "Interval koefisien antara 0,60-0,799 adalah kuat."

Sedangkan koefisien determinasi 39,69\% hal ini menunjukkan bahwa pelayanan Kartu Tanda Penduduk (KTP), Kartu Keluarga (KK) dan perizinan dapat dipengaruhi oleh akuntabilitas kerja sebesar 
$39,69 \%$. sisanya sebesar $60,31 \%$ dipengaruhi oleh faktor lain yang tidak dibahas dalam penelitian seperti fasilitas kerja, kepemimpinan dan sebagainya.

Hasil analisis regresi dengan persamaan $\mathrm{Y}=2,50+0,67 \mathrm{x}$ dapat dijelaskan konstanta sebesar 2,50 menyatakan bahwa, jika tidak ada kenaikan nilai dari variabelakuntabilitas kerja, maka nilai pelayanan adalah 2,50. Koefisien regresi sebesar 0,67x menyatakan bahwa setiap penambahan 1 (satu) skor atau nilai variabelakuntabilitas kerja akan memberikan peningkatan skor pelayanan Kartu Tanda Penduduk (KTP), Kartu Keluarga (KK) dan perizinansebesar 0,67 atau setiap variabelakuntabilitas kerjadinaikkan sebesar 100\%, maka pelayanan Kartu Tanda Penduduk (KTP), Kartu Keluarga (KK) dan perizinanakan meningkat sebesar $67 \%$, hal ini berlaku jika diasumsikan variabel-variabel lain dalam penelitian ini konstan atau ceteris paribus.

Hasil uji $t$ yang diperoleh akan dibandingkan dengan harga $t_{\text {tabel. }}$. Untuk kesalahan $5 \%$ uji dua pihak dan $\mathrm{dk}=\mathrm{n}-2=98$ yaitu 8,09, maka diperoleh $t_{\text {tabel }}=1,980$ maka dapat dikatakan $t_{\text {hitung }}>$ dari $t_{\text {tabel }}$. Sehingga dapat ditarik kesimpulan bahwa $\mathrm{H}_{\mathrm{a}}$ diterima Ini berarti akuntabilitas kerja berpengaruh terhadap pelayanan kartu tanda penduduk (KTP), kartu keluarga (KK) dan perizinan pada Kantor Camat Badiri Kabupaten Tapanuli Tengah.

\section{KESIMPULAN DAN SARAN}

\section{A. Kesimpulan}

Berdasarkan hasil analisis dan pembahasan data yang dilakukan pada uraian sebelumnya dalam penelitian ini, dapatdiambil kesimpulan sebagai berikut :

1. Berdasarkan hasil penelitian terhadap 100 responden, menunjukkan hubungan antara akuntabilitas kerja terhadap pelayanan adalah kuat, dimana koefisien korelasi diperoleh 0,63

2. Hasil perhitungan koefisien determinasi diperoleh 39,69\% hal ini menunjukkan bahwa pelayanan Kartu Tanda Penduduk (KTP), Kartu Keluarga (KK) dan perizinan dapat dipengaruhi oleh akuntabilitas kerja sebesar $39,69 \%$. sisanya sebesar $60,31 \%$ dipengaruhi oleh faktor lain yang tidak dibahas dalam penelitian seperti fasilitas kerja, kepemimpinan dan sebagainya.

3. Berdasarkan model regresilinear sederhana yang diperoleh persamaan regresi adalah $\mathrm{Y}=2,50+0,67 \mathrm{x}$ menunjukkanhubungan antaraakuntabilitas kerja terhadap pelayanan kearah yang positif.

4. Berdasarkan uji $t$ diperoleh sebesar 8,09 dan $t_{\text {tabel }}=1,980$, maka dapat dikatakan $t_{\text {hitung }}>$ dari $t_{\text {tabel }}$ dapat ditarik kesimpulan bahwa $\mathrm{H}_{2}$ dapat diterima.

\section{B. Saran}

Berdasarkan kesimpulan tesebut di atas, maka penulis merasa perlu memberikan saran dan masukan yang berguna untuk instansi yaitu,:

1. Hendaknya sarana dan prasarana yang ada di Kantor Camat Badiri perlu ditingkatkan serta diperhatikan perawatannya, supaya ketika dipergunakan oleh pegawai dapat bermanfaat untuk kegiatan operasional sehari-hari. Ada beberapa fasilitas yang harus diperhatikan perawatannya, misalnya meja dan kursi yang kurang layak harus dicat ulang, filling cabinet yang harus ditambah, komputer jugaharus di upgrade dan penambahan printer yang dilengkapi scanner.

2. Dalam hal ini, pemimpin juga harus memperhatikan faktor-faktor yang membuat pegawai termotivasi, baik keinginan kebutuhan maupun harapan dari masing-masing pegawai. Dengan terpenuhinya keinginan pegawai, maka otomatis para pegawai akan berusaha menampilkan kinerja yang terbaik yaitu memberikan pelayanan prima pada masyarakat.

3. Perlu ada kejelasan mengenai biaya, kepastian waktu untuk masyarakat yang ingin mendapatkan pelayanan dari Kantor Camat Badiri. Hal ini sangat penting supaya jangan ada masyarkat yang merasa diperlakukan tidak adil.

4. Perlu adanya pendidikan dan pelatihan dari pemerintah untuk aparatur untuk meningkatkan kemampuannya berorganisasi, baik itu penguatan capacity building maupun institutional building. Hal ini sangat perlu karena aparatur Kantor Camat merupakan ujung tombak yang terakhir yang langsung berhadapan dengan masyarakat memberi pelayanan. 
5. Dari segi pelayanan publik, hal yang perlu ditingkatkan adalah kualitas yang sudah dibangun untuk menciptakan kepuasan masyarakat dipertahankan dengan sikap ramah pegawai, berpenampilan baik serta mengerti kebutuhan dan menindaklanjuti keluhan yang disampaikan oleh masyarakat. Selain itu pelayanan hendaknya dilakukan secara lebih mudah cepat dan sesuai dengan prosedur dan perundang-undangan yang berlaku.

\section{REFERENSI}

Bambang Istianto, 2009, Mewujudkan Good Governance Melalui Pelayanan Publik. Yogyakarta : UGM Press

Boediono. B, 2003, Pelayanan Prima Perpajaka,Jakarta : Rineka cipta

Gambir Bhatta, 2006,Capacity Building at the Local Level for Effective Governance, Empowerment without Capacity is Meaningless

Handayaningrat, 2009, Peranan Aparatur Pemerintah. Jakarta : Sinar Harapan

Koesoemaatmadja, 2009,Mewujudkan Good Governance Melalui Pelayanan Publik. Yogyakarta:Pustaka Pelajar

Miriam Budiarjo, 2010,Etika Administrasi Negara. Edisi. Ketiga, Cetakan Kedua Belas. Jakarta : Raja Grafindo Persada

Keputusan Menteri PAN Nomor. 63/KEP/M.PAN/8/2013 tentang Petunjuk Teknis Akuntabilitas dan Transparansi Dalam Penyelenggaraan Pelayanan Publik.

Siagian, Sondang P, 2007, Teori dan Praktek Kepemimpinan, Cetakan Kelima, Jakarta : Rineka Cipta

Sianipar, J. P. G, 2001, Manajemen Pelayanan Masyarakat, Jakarta : LAN

Sinambela Lijian Poltak, 2006, Kebijakan dan Implementasi, Reformasi Pelayanan Publik, Jakarta: Bumi Aksara

Saparin, 2006, Peranan Aparatur Pemerintah. Jakarta : Sinar Harapan

Sugiyono, 2005, Metode Penelitian Bisnis, Cetakan Ketujuh, Bandung : Alfabeta

STIE Al-Washliyah Sibolga/Tapanuli Tengah, 2015, Pedoman Penulisan dan Penyusunan Skripsi, Sibolga

The Liang Gie, 2008,Pertumbuhan Pemerintahan Daerah di Negara Republik Indonesia. Jakarta : Gunung Agung

Tingkilisan Hessel S, 2005, Manajemen Pelayanan Publik, Jakarta: Grassindo

Zauhar, 2006, Hukum Administrasi Pemerintahan di Daerah. Jakarta : Sinar Grafika. 